\title{
III.-THE ORIGIN OF THE SUBLIME
}

TukRe is perhaps no feeling in our nature more strangely compounded and more indefinably singular than that which we call the Sense of the Sublime. It is not exactly pleasurable, and yet it certainly is not painful. It has many elements in common with fear, many in common with reverence, and not a few in common with beauty. Yet it stands apart from all three, in an isolated corner of its own, and it has seldom received any fitting attention at the hands of scientific psychologists. Most writers have classed it roughly amongst the esthetic feelings, but hardly, I think, with sufficient reason. Perhaps an analysis of its origin in the human mind will lead us to a truer notion of its nature and functions.

If we go back to the very first germ from which the feeling of the Sublime has been developed, we must seek it lower down in the animal scale than the limits of humanity itself. The desire to produce an effect is one which man shares with many of the higher vertebrates. If we watch monkeys at play, we shall notice how keenly they enjoy the power of startling or surprising their fellows. They love to pull one another's ears unexpectedly, to jump on a sudden from a height, or to make a smaller comrade squeak aloud with pain. Dogs are equally anxious to obtain notice by jumping over a stick, or exhibiting their skill in tricks. Many animals evidently delight in the loudness of their own roar or cry, while still more strut proudly about in the triumph of victory over their rivals. In many ways birds and mammals show us that they understand and appreciate the simpler pleasures of power and display. And as all power is an index of success in the struggle for life, this feeling is clearly conducive to the preservation of individuals or races in whom it exists, and consequently is continually strengthened under the selective action of survival of the fittest.

When we come to the younger members of our own species, we find similar feelings more developed, and more highly evolved. Babies in arms will crow with delight at knocking down a tea-cup, or making a loud noise. Schoolboys enjoy nothing so much as a crash or bang-they are perfectly happy with an ounce of gunpowder or half-a-dozen squibs; and they delight in rolling big stones down hillsides or driving horses and cows full-pelt across a meadow. An exhibition of what they can $d o$ is their greatest pleasure: and this feeling, again, is clearly one which contributes greatly to the success in life of those races which possess it.

Hence arise two or three important impulses, which pave the way for the sense of Sublimity. One very conspicuous method 
of proving one's prowess is by the performance of deeds requiring strength and skall. Every savage is proud of his warlike achievements, and is urged on by the admiration of his fellows. This admiration itself has a double origin : it is partly selfish, depending upon the fact that a strong and brave man is a shield and buckler to every member of his tribe; and it is partly sympathetic, in an incipient degree, depending upon the consciousness of self-approval for similar qualities in one's own case. The earliest embryo of the Sublime is doubtless to be sought in this savage appreciation for the brave warrior of one's tribe. The man whose strong arm comes in to save one from the club of one's foe, deserves lasting gratitude and admiration. The hero who leads the attack against the enemy, and successfully carries away cattle and wives, is an object of respectful awe. The Hector who alone wards off from his Troy a myriad of Myrmidons, demands the obeisance of cowards and women.

Probably this is the only form of the Sublime which is reached by the lowest types of humanity. We can hardly imagine the early races, who are still represented by Veddahs and Andamanese, admiring the vault of heaven or the foaming cataract, the lofty mountain or the angry sea. Yet even in this primitive germ, we see the main traits which mark the feeling of Sublimity in its highest flights. It is a mixture of love and dread. The savage knows the value to himself and his fellows of the strong warrior, and treats him accordingly with genuine respect; but he knows also how dengerous is his anger, and regards him consequently with awe and reverence. His feeling is very different from that with which he thinks of his enemy-there, hatred and fear are unqualified by that respect which is begotten from the hope of aid; but it is also very different from that with which a civilised man thinks of his friend-pure affection, unmixed with fear. Perhaps the nearest emotion within the range of our own experience is that which a child entertains towards his parents. In a crowd of strangers he clings to them as known friends, but he never forgets that they are also the dispensers of punishment, and keepers of the whip.

There are few societies of men in which the strongest has not come in time to occupy the post of chief or king. As this position strengthens and hardens down by custom, the feeling of awe and respect deepens. The absolute monarch, with power of life and death over every subject, is a natural object of dread. Yet he is also the leader of the host, the dispenser of favours, the divider of the spoil. If implicit obedience to his will is demanded of all, yet that obedience, when willingly granted, generally secures benefits for the subject. And as the tribe profits by its discipline and its military organisation, there will 
naturally grow up in all successful predatory tribes, an intense feeling of loyalty and reverence for the king - a loyalty culminating in that of the Fijians, who consider it an honour to become food for their chiefs. The second stage in the evolution of the Sublime is found in the veneration for the savage king.

But when the king dies, he does not utterly pass away." A new king rises in his place, who was once his subject, and who, dreading him during his lifetime, now still more dreads and reverences his surviving ghost or double. The people too, who fear the new king, must still more fear the ghost which the king himself is afraid to displease. Yet their feeling is not wholly ove of terror. The ghosts of enemies are indeed objects of unmitigated dread ; but the king of their own people, though terrible as all ghosts are, nevertheless aids them in the fight, and drives away the evil spirits of the hostile tribe. He can be propitiated with gifts, and he is still the powerful if somewhat uncertain friend of his former subjects. As in life he was harsh yet invaluable, so in the spirit-world he is easily offended yet placable to his tribesmen, and their steadfast ally against all enemies, earthly or ghostly. And inasmuch as this feeling, too-by binding together the tribe, and adding a supernatural element of subordination to the natural one of kingship-increases its organisation, and strengthens its hands against aggressors, it, like the former ones, is perpetually developed and deepened through the natural selection of those societies which most display it. The third step in the evolution of the Sublime is the mixed feeling of fear and hope with which savages regard the earliest god, the ghost of their deified chieftain.

By this time the sense of Sublimity has reached a very considerable distinctness. It is true that it still confines itself to human or quasi-human attributes, and that the infinitely wider Sublimity of nature is as yet all but unperceived. We shall see hereafter how that conception is gradually developed through the anthropomorphic mode of envisaging the inanimate world which springs from the extension of the ghost-theory. For the present we may confine our attention to the expression of Sublimity at this, its third, stage. The tales which savages tell, and the songs which they sing around their evening fire, all bear upon the mighty deeds of kings, heroes, and gods - the three being almost indistinguishable in the earliest types. The South Pacific myths which Mr. Gill has collected and published, or the New Zealand stories narrated by Sir George Grey, show us a conception of the Sublime which never rises above this simple

- I had better here acknowledge, once for all, my obligations to MIr. Herbert Spencer's Principles of Saciology, on which I hase the whole of my theory, вo far as regarls the comparative science of religions. 
level. These races have no great architectural piles which might aid them in extending the feeling to inanimate masses, nor have they progressed to the anthropomorphic conception of natural forces, which enables other stocks to embrace the thunder and the storm, the seething ocean and the driving cloud, within the limits of their sense of Sublimity. Among all the embryonic literature of tribes in the stage of theology here contemplated which has yet been rendered accessible to European readers, I can find scarcely a touch that reveals any admiration or awe for the might of the external universe. The strength of men, the terrible deeds of gods, the ghosts of men, are held up to the wonder and veneration of every hearer; but not a trace can be found of any reverential feeling for the grandeur and majesty of the mighty world around them.

A little higher up in the scale of development, however, the spiritual agency widens its sphere of operations. Without inquiring into the rexed question of how the ghost or deity comes to be identified with the moving power of inanimate nature, it will be sufficient for our present purpose if we recognise the fact that he does come to be so identified. The howling of the wind is the voice of a god; the rumbling of the thunder is his angry roar ; the tempest on the ocean is stirred up by his trident; he dwells in the flaming volcano, and his blast drives aloft the molten lava; he lies under the roots of mountains, and when he turns upon his side an earthquake rends their bases. If the gods were only this, however, they would be merely an object of unmixed dread and horror; the feeling of Sublimity would never reach any higher development, and hatred or abject fear would take its place. But the gods have also their kindly side as before. It is they who send the rain and the breeze; it is they who grant plentiful harvests and abundant flocks; it is they who are the dispensers and distributors of all good things. The Roman Ceres fills the garners, and Dionysus swells the grapes of Hellas. Some of them are identified with the greater natural agents whose beneficence is obvious and undoubted. One is the warm sun who shines on the fields and gives the pleasant light of day. Another is the bright and changeful moon who comes to the aid of man in the darkness of night. A third is the clear open sky above, whence fall the quickening showers that nourish the crops. Every day yields abundant proof alike of their might and their good-will. Zeus may indeed collect the angry thunder clouds and blast the mountain-top with his fiery dart; but he oftener smiles benignly on his children, with that

- Even where a tinge of the Sublime in nature is cast upon the story by a passing expression, we must gaard against the porsible danger of reading our ofn ideas into the simple and positive language of the savage. 
serene brow which well befits the father of gods and men. Awe for their power mingles strangely with hope of their favour in the minds of their votaries. Mighty and strong and irresistible they are; yet they may be turned aside by prayer and propitiated by the savour of perfect lambs and bulls.

How enormous is the amplification which this anthropomorphic envisagement of nature gives to the sphere of the Sublime we can see at a glance. The savage who has only just progressed beyond the first stage of the ghost-theory can hardly stand awestruck before the majesty of nature. The thunder is doubtless very terrible to him, and the cold wind very unpleasant; while the warmth of the sun and the coolness of the breeze are agreeable and grateful to his senses: but as he does not connect them with any underlying power, they seem to him no more than so much dead fact, without complex emotional implications. As soon, however, as he learns to see in these manifestations the acts of some occult and invisible being, he cannot fail to compare their vastness and might with the smallness and weakness of his own powers. His idea may still be a childish and an unworthy one; he may still fancy that these unseem spirits can be deceived and cajoled by the most transparent trickery ; he may still hope to outwit them through craft or to frighten them with threats ; but nevertheless he must recognise them as something vastly greater than mere human kings; he must.take the decisive step which definitely marks off the god from the simple ghost.

If we examine such a monument of the differentiated theological stage as we possess in the Homeric ballads, we shall see how deep a hold the sense of Sublimity has there obtained over the awakening intelligence of men, no longer barbaric, but far on their way to an advanced culture. But we shall also find these four first developments of the feeling-awe towards the hero, towards the king, towards the gods, towards the divine motive power in nature-filling the whole field to the exclusion of all those more complex and elevated factors which enter into the composition of the Sublime in its highest forms. The wrath of Achilles, the waving plumes of Hector; the strong warriors of yore, amongst whom Nestor fought ; the heroes of elder days, Bellerophon, Tydeus, and the might of Heracles; wide-ruling Agamemnon, Priam, and Memnon, and all the Zeus-nurtured kings; the gods of Olympus, of Hades, and of Ocean; Ares stalking before the hosts of men; Phcebus Apollo, angry in heart; Zeus assailed by the Titans who pile Pelion upon Ossa, or calling to his aid Briareus of the hundred hands; -in all these we see the feeling of awe and reverence for the strong man, the chief, the king, the deified hero, and the god whose human 
origin is forgotten in the dimness of past centuries. But if we look for any sense of admiration towards the great moving powers of nature, we shall find it only under an anthropomorphic guise. Poseidon the earth-shaker rouses the white billows on the limitless deep: Apollo the far-darter drives his golden car through the divine æther: Zeus the loud-thunderer collects the black clouds and darts his angry bolts upon the perjurer's head. Yet amid all this wealth of anthropinistic sublimity - a wealth which perhaps no other literature can equal in its own waywe miss any feeling for the sublime of nature in repose, any sense of grandeur in sea and sky and mountain, apart from the great shadowy beings who dwelt within them and gave life and motion to their mighty masses.

And here again we see how intimate is the connexion between the feeling of the Sublime and the sentiment of subordination. The Homeric Achæan is after his kind a law-loving man. He feels and recognises the necessity for union under a lawful chief. The rule of many is not good; let one alone be king whom Zeus appoints. The king it is who guards the divine laws, derived from Zeus. It is folly to disobey the word of one who reigns over many islands and all Argos; for a king is much the stronger when he is wroth with a man of low degree. Yet the king's sternness does not disguise the fact of his usefulness both as warrior and as leader. Nor is his power entirely his own; he holds it on sufferance of Zeus, who will not allow his divine laws to be lightly set aside. The gods themselves, too, are often harsh, yet they are kindly in their softer moods. Angry Phobus sends a pestilence, but he may be propitiated with hecatombs, and with a lustration whose sanitary effects must obviously be useful in checking the arrows of the god. Zeus watches over the faith of treaties, and punishes the perjured head Artemis avenges the loss of chastity. Demeter puts forth the green corn; Athene gives the olive; Dionysus sheds bis wine into the vats. With the might of Ares men conquer in battle; by the counsel of Fallas they speak words of wisdom in the Agora. In one way or another every one of these beliefs gives some point of superiority to its votaries, by hedging round with sanctity an ethical observance, by promoting a useful social custom, or by giving confidence in war or debate to the warrior and the orator. And with every such advance the feeling of Sublimity must grow more and more definite, more and more structurally innate, in the minds of each new generation amongst the successful races of mankind.

If we step aside for a moment from our main line of exposition to compare the monarchical Achæan ballads with the later democratic Athenian drama, we shall see how the change of 2 ? 
political circumstances influenced the sense of the Sublime. The Attic tragedians show as a measured and self-respecting religious feeling, which pays all due honour to the gods. But the reverence of the king has passed away. We do indeed see traces of the legendary monarchical feeling, introduced as historical colouring; but the democratic sympathies of the writers crop out at every turn. Agamemnon treading on the carpet, Ajax mad, Xerxes and Atossa infatuate and defeated, the ragged heroes of Euripides, the ribald irreverence of Aristophanes, are a few indications of the change. The heroes speak in noble and austere language, but it is the language of moral suasion, $\mathrm{c}^{f}$ deliberate counsel, of thoughtful resolve. When Ajax lies unburied, when Philoctetes is cajoled into the power of his enemy, when Antigone is dragged away to slaughter, when Polyxena is torn from her mother's arms, all the sympathies of the audience are with the oppressed against the tyrants. But when we turn to divine matters, the spirit of subordination is once more apparent. Prometheus welters on the snowy rocks of Caucasus, a rebel against the irresistible might of Zeus; Orestes is driven madly over the stage by the awful figures of the Eumenides; until be clears himself of blood-guiltiness before the solemn tribunal of Phœebus; Pentheus is torn piecemeal by the Bacchants for daring to interdict the holy orgies of Dionysus. Even if we compare the tragedians among themselves we see somewhat the same differences in the earlier and the later. Aschylus the religious conservative is full of awe for gods and heroes, of respect for time-honoured institutions, of modified veneration for the great monarchs of early legend; but Euripides the philosophical radical loves to exhibit the folly and the passious of kings, and has little reverence even for the great gods themselves. Occasionally, too, in the works of the glorious Athenian period we find tinges of a higher and grander Sublime; as in that marvellous lyrical spectacle, the Perse, where the poet impresses upon his audience a full appreciation of that noble sight, a free people banded together under their own chosen leaders, fighting for liberty and culture against the aggressive hordes of a barbaric despot. "We too have a master," says the free Hellene to the Oriental tyrant, "whom we serve far better than your slaves serve you, and his name is Law".

But we must return from this digression to follow' out the development of the Sublime in its regular historical course. There is another element of sublimity which has arisen earlier, perhaps, than those already considered, but which introduces a somewhat different original factor, and so has been postponed to the present place. I mean the element of material bigness in human or natural products. To put the difference briefly we 
may say that the elements we have so far examined depend for their impression on force; while the present one depends on size.

Originally, we saw, the notion of the Sublime took its beginning from the effects which a man could produce, and especially from the strength or agility of the strongest. Thence it progressed to the power of kings, of ghosts, of gods, and of natural agents anthropomorphically conceived. In all these cases it is evident that the main idea is one of superior force, exercised in a manner not wholly adverse, or rather partially beneficent, to the individual, the tribe, and the race of men generally. But how did the sense of Sublimity come to entwine itself around the physically big, viewed in repose? I think this element of the Sublime is itself ultimately resolvable into the same admiration for superior force, always, of course, in alliance with the subordinative sentiment, governmental or religious. Let us see how,

Among the commonest instances of that love for the production of an effect, which we took as the psychological startingpoint of our inquiry, is the erection of a conspicuous mass of matter. Children make sand-heaps and big snow-balls, or build card-houses and castles of bricks. Savages pile bartows over their dead, raise huge cairns on mountain tops, and lift massive stones into cromlechs, avenues, and monolithic circles. In all these acts, they can gratify the natural love of effect, the desire to do something which shall produce a striking and noticeable change in the surrounding scene. Especially do primitive men enjoy the power which they thus possess of giving a permanence to the form which they impress on large masses of matter. But when we reach the developed kingly stage, we find this impulse taking a fresh start in the direction of vicarious effort. A great king shows his power by the number and strength of his subjects, the implicit obedience of his vast armies, the hundreds of captured cities, the thousands of slaughtered or mutilated foes; but he can also show it by building for himself or his ancestors, palaces, temples, tombs, and colossal statues. Hence we find that almost all great despots erect huge piles of architecture to demonstrate their might, and strike wholesome awe into the brensts of their subjects. Whether we examine the Pyramids, the Sphinx, the Memnon, and the temples of Karnac, or turn to the winged bulls and sculptured courtyards of Nineveh, we shall notice alike that architecture is devoted to the aggrandisement of the king and the due subordination of the subject. The lesson preached in every bas-relief and every painting is the same: obey the great king who is the taker of cities and the ruler of peoples. If from the palaces and tombs 
we turn to the temples, we find the religions tie added to the governmental. A huge hall, with row after row of mighty granite columns, and a colossal figure of the tutelary god, strikes deep reverence into the mind of the beholder. In whatever part of the world we look, we see the same story repeated. From the caves and topes of India to the pyramids and temples of Mexico, we see architecture everywhere allied with despotism and the religious subordination. Even in republican communities, like Athens and Rome, the sacred use survives, and the home of Athene on the Acropolis or of Jupiter on the Capitol peers down with lordly disdain upon the lesser roofs of men and citizens.

Indeed, it would be interesting, did space permit, to point out how very close and almost invariable is the connexion here hinted. It would be necessary then to show how imperial Rome, with her Domus Aurea, her Colosseum, her Baths, her Triumphal Arches, her Basilicas, followed in the wake of ancient Memphis and Babylon: how, in later times, the Medici adorned Florence, and then Rome: how Louis XIV. had his Versailles, and Napoleon III. his new Paris. We might pass over to the mosques with which the Mughal dynasty adorned the plain of Delhi, and to the palaces and pagodas of Pekin. And we might glance at our own European Cathedrals, and trace the changed aspect of governmental machinery in the Parliament Houses of Westminster, the Capitol at Washington, or the disproportionate and costly mass of Gothic edifices which the Canadians are raising for public offices at Ottawa. But such a survey would detain us too long, and the instances thus rapidly cited will serve' to suggest to the mind of the reader how large a share, in the development of the political and ecclesiastical restraining system, has been borne by mere mechanical vastness in the machinery employed.

Now, with the growth of such massive and laborious piles must come the appreciation and admiration for their size and structure. The boy when he has rolled his big snowball, the savage when he has lifted on end his monstrous monolith, the despot when he has heaped his colossal pyramid, each stands by to admire his work, and feels his heart swell with pride at the effect of his personal or vicarious labours. The boy's comrades, the savage's fellows, will join him in a sympathetic appreciation; while the subjects of our primitive despot will see another mark of that god-like power and infinite superiority which is daily impressed upon them in ten thousand ways. Whoever looks upon their piles, even to this day, cannot fail to think upon the thousands of workmen, the years of toil, employed in raising those solid blocks of granite, one above another, to so lofty a 
height. And on those who lived amongst them, and saw with their own eyes, year after year, the Great Pyramid rising slowly towards the sky, some vague feeling of awe for the visible symbol of majesty could not fail to be impressed. We can hardly doubt, I think, that the admiration for what is vast in the outer world must be ultimately traced back to the admiration for what is vast in the works of man: just as we have already seen that the forces of inanimate nature only excited wonder and reverence when they came to be figured in terms of human force. Children admire a big building or statue long before they have developed the feeling of admiration for a mountain or a waterfall.

It is hardly necessary to add that the skill, the mechanical power, and the organisation, evolved during the gradual growth of such works, themselves form useful aids to the race in the struggle with other races, and ultimately beget that higher civilisation which enables its possessors to compete on terms of immense superiority with every inferior type of humanity.

As yet, however, we have not seen how the sublimity of nature-in-repose first comes to be appreciated. In modern times, the most obvious instances of the Sublime which strike us are those of ice-clad mountains, tottering crags, deep ravines, cataracts luke Niagara, the broad expanse of ocean, and the starry vault of heaven. Yet not one of these seems to produce much effect upon men up to a very high pitch of culture. The Greeks and Romans, even, were little impressed by them. The Alps they regarded mainly in the utilitarian light of so much useless ice and snow, placed on the highroad to Gaul and Germany. - Mountains are to them nothing more than mere barriers; their epithets are mostly shadeless, barren, inhospitable, chilly. The ancient cultivated nations admired much the picturesque in scenery or in man's handiwork, and the grand in human nature or divine beings : but they cared little for mere vastness in the external world. There is a certain mode of teviewing our own feelings on the subject which, I think, will show us the reason for this difference.

Very few people feel any thrill of Sublimity as they look over a very wide and flat plain, a level expanse of sand, or a calm and unbroken stretch of sea. But if in the midst of the plain a few bold rocks rise threateningly on high, their admiration is at once arrested. The position of the rocks inevitably suggests some vague notion that they were mut there; and in this suggestion we get a point of comparison with human force: while the flat plain seems, so to speak, as though it were naturally there, and does not at all vividly suggest the notion of any human or supermatural agency at work. So, too, with the sea: 
while it remains calm, we see in it only a beautiful field of soft blue colour; but when a tempest raises its waves, we picture it to ourselves as angry, as violent, as a living thing; we compare its roar, its sweep, its tremendous energy, with the puniness of our own arms, of our drifting ships, and of our beaten breakwaters. Again, in proportion as the mass of a mountain is great, and its sides abrupt, we think more and more of the gigantic power which would be required to pile it to such a height. But we do not see the pawer at work. If, however, we watch a volcano in eruption, the feeling of Sublimity is enormously increased. In fact, wherever there is an actual display of energy, the sense of Sublimity is most strongly aroused : where the energy is only suggested, the emotion is comparatively vague: and where energy does not enter at all into the idea, Sublimity is not suggested by the mere bigness of an external object. We require some hint which will assimilate the objeot to a human product before we can find in it a germ of the Sublime.

Now to all modern minds the notion of the world as created, as made by God, has been familiar from childhood. The idea of force exerted in raising every mountain, in planing every crag, in scooping out every ravine, is immediately suggested to our minds together with the objects themselves. I do not say that we all accept the direct theory of creation in its crude form : but even those of as who have substituted the scientific conception of natural causes for the older belief in personal divine intervention, still carry about with us predispositions of thought which were contracted under the earlier creed. Indeed, we see the energies involved even more clearly than do those persons who still envisage them in the vague metaphors of religion. When we stand in the riven gorge of Pfäffers or the water-worn ravine of the Niagara, we can realise the endless working of that slowly encroaching power with far greater vividness than the unscientific thinker can give to his verbal picture of rocks rent asunder by the finger of God. Yet the old school and the new school of moderns are alike in this, that they see indications of moving energy, natural or supernatural, in every conspicuous mass of the material universe. The ancient cultivated races, on the other hand, seldom or never inquired how the universe came to be there or assumed its existing form; they accepted it simply as given, or if they made any conjecture on the subject, they concluded that it had been there as it was, from eternity." We of to-day, whether we see in a mountain a piece

- Sach exceptional cases as that of Lucretius an embryo Laplace or Darwin-will be noticed hereafter. For the present it will be sufficient to observe that such persons had a feeling of the Sublime infinitely raised above the arerage level of their time and race. 
of God's own handiwork or a product of enormous ernptive forces, at any rate think of it as raind: the Greek or the Roman simply thought of it as lying. And if we go back to the origin of this feeling on our part, I believe we must seek it in the Hebrew cosmogony. For when we search for any sense of Su'Jlimity in the old world at all comparable to that which is common in the new, we find it only in the wonderful prelude or Genesis, the mystical visions of Ezekiel, and the thundering periods of Job.

The mere savage never asks who made the world. It you put the question to him, he thinks it childish and absura-the world was always there of course. Even to the Greek'snd the Roman, the gods were a part of the world:-they sprang it, they moved in it, but they did not make it. The unirene was as objective to Zeus as to his worshipper: it lay quite outside the sphere of divinity. The gods wrought on it no man wrought on it: it was their material, and they gave it sometimes a new shape. But that short declaration, "In the beginning God created the heaven and the earth," contained the germ of a whole new development for the sense of the Sublime. Even Longinus noticed the wonderful majesty of the primæval fiat"Let there be light, and there was light". Indeed, monotheism in every way offers immense opportunities for the evolution of the Sublime. By substituting for the many opposing and mutually-limiting gods of the polytheist a single supreme and infinite God, it concentrates on one point all the veneration and love of his worshippers. And when this God comes to be conceived as the maker and architect of the universe, the sense of his irresistible might becomes overwhelming. Nature is thought of as his outer manifestation. The heavens declare the glory of God, and the firmament showeth His handiwork. They are the work of His fingers: the moon and the stars $\mathrm{He}$ has ordained. The earth is the Lord's and the fulness thereof, the world and they that dwell therein. By the word of the Lord were the heavens mode, and all the host of them by the breath of His mouth. When He speaks out of the whirlwind to Joh, man learns his own weakness and folly, by the measure of his maker. "Where wast thou when I laid the foundations of the earth? Who hath laid the measures thereof, if thou knowest?" Behemoth and Leviathan testify to His might. The mountaing skip before Him like a calf; He rideth upon the heavens, and the earth is His footstool, the hill of God is as the hill of Bashan, an high hill as the hill of Bashan. There is more true sublimity in half a dozen Psalms or four chapters of Job than in all the odes of Pindar and all the tragedies of Fsschylus.

But here again, as in every other case, we find an under- 
current of love and trustfulness, half hidden beneath the sense of reverence. The God who created heaven and earth is emphatically the God of Israel. He has made an everlasting covenant with His chosen people. $\mathrm{He}$ is not a man that $\mathrm{He}$ should lie, and $\mathrm{He}$ is of purer eyes than to behold iniquity. But His mercy endureth forever; He hath not despised nor abhorred the affliction of the afflicted, neither hath $\mathrm{He}$ hid $\mathrm{His}$ face from him. "The Lord is my shepherd," the poet can sing; "I shall not want. He maketh me to lie down in green pastures; He leadeth me beside the still waters." "I, even I," says Jehovah, by the mouth of His prophet, "am He that comforteth you : who art thou, that thou shouldest be afraid of a man that shall die, and of the son of man which shall be made as grass, and forgettest the Lord thy maker, that hath stretched forth the heavens, and laid the foundations of the earth ?" In every line of the Hebrew poetry and every page of the Hebrew chronicles we see this overwhelming conception of the might and majesty, the loving care and protection, of the God of Israel.

It is needless to point out how this feeling, too, was an element of success in the battle of races. The monotheistie creeds have spread irresistibly from Hindustan to California, and have proved by incontestable results their ability to hold their own in conflict with every inferior faith. Nowhere can the heathen oppose a solid front to the aggressive hosts of Christianity and Islam.

The modern world, nursed upon the grand utterances of the Hebrew bards, has imbibed the sense of the Sublime almost with its mother's milk-nay, one may even say, before it. For every one of us is now born into the world with a hereditary capacity for that mingled feeling of awe and security which constitutes the essence of the Sublime. The feeling is not entirely pleasurable; it is partly ethical and subordinative. It passes very readily into fear and distress, as in the case of a thunderstorm, a tempest at sea, or a volcanic eruption. Even such a terrific gorge as the Via Mala, or such a cataract as the St. Lawrence rapids, is rather frightening than impressive. Cliffs and crags give us a more agreeable sensation viewed from a slight distance than when we stand just beneath their threatening mass. But they all yield us a certain sympathetic pleasure as evidences of power, natural or divine. The stock reflection of moralists on all such subjects is the puniness of man and the power of his great Creator. I find in a little guide-book to Niagara eight pieces of verse by different hands, every one of which turns as a pivot upon the self-same idea. The religion which for twenty centuries has taught us to see everywhere some token of the greatness and goodness of God, is now 
engrained in our nervous systems, and produces its effects unconsciously in our everyday life.

A last question remains. Will the sense of Sublimity decrease as the notion of fixed law supersedes that of capricious divine interposition? There are good reasons for thinking that it will not.

The progress of scientific thought has opened before us a field for the exercise of our faculty of Sublimity almost as new and extensive as that which was laid open by the monotheistic creed and the doctrine of creation. The microscope has revealed to us the marvellous intricacy of coral and shell and zoophyte: it has shown us the feathery scales on the butterfly's wing, and the countless facets of the insect's eye: it has made visible the minute structure of every animal tissue, and the complicated architecture of every vegetable fibre. In each of these the man of science saw fresh proofs of design and power, which have slowly led the way towards a new conception of Sublimity. Meanwhile, the telescope enlarged our view from the solid firmament of the Psalmists to the boundless realms of space which the eye of a Newton or a Herschel sees peopled with innumerable suns, and countless systems of eddying worlds. Geology taught us to look back, not over a few thousand measurable years, but over immeasurable æons of historic time, stretching back into a vast and unknown past. And now we have learned to picture our earth as a speck of matter floating in an ocean of space, and our era as a second of time marked on the infinite dial of eternity. Through a boundless void which our miles cannot measure, through an endless period which our centuries cannot gauge, we see the workings of that infinite, absolute, unknowable Entity, which manifests itself eternally in the heavens and the earth and the soul of man. We spell out its operations in the fiery sea from which sun and planet drifted towards their appointed centres; in the slow growth of living forms upon their cooling crust; in the myriads of beautiful beings which people a drop of water; in the noble aspirations and earnest moral yearnings of the human race. Surely our idea of the ultimate Being has not been lowered or degraded by this vast extension of our knowledge and our vision !

But perhaps it may be objected that we have here only the awful side of the Sublime and not its comforting or protecting aspect. Perhaps to a certain extent this is true: and indeed, every step in the evolution of the feeling has made the centre round which it gathered more awful because more absolutely and indefinitely powerful. But at the same time, each step has brought with it a limitation in the capriciousness, the favouritism, the uncertain demeanour of the being-man, king, ghost, 
or god-towards whom the sentiment was principally directed. And in this last substitution of a Power working through knowable laws, for a Power working by inscrutable volitions, we get a further advance in the same direction. There is an element of pleasure in the certainty and security of Law. No comet now brings war or pestilence; no portents and prodigies disturb our peace and demand propitiatory sacrifices. We rest on the safe ground of known causes: and when danger threatens we can meet it by our own manful endeavours, not by slavish submission. Pestilence can be warded off by sanitary care; famine by wise precaution; war by prudent and moral selfrestraint. The great Power which underlies the universe will not repent of acts done or wreak capricious vengeance on offenders. We can go on fearlessly upon our path, obedient to the great natural laws without us, and the ethical principle which is developing within us; and we need tremble at no bugbear of superstition, as we pursue our onward and upward course, towards fuller knowledge and purer life.

And here we may turn back to notice how the truest conception of the Sublime has always been that of those men who were most in advance of their age. The poet who knew that the best of omens was to fight for one's fatherland-the prophet who knew that God would have righteousness and not burnt-offerings - these are they who feel the deepest thrill of the Sublime, and speak it out clearest for our hearing to this day. And among the solid matter-of-fact Roman people, the solitary singer whose words still ring in our ears for their sublimity was the one who knew the reasons of things and trampled under foot fears and inexorable doom and greedy Acheron's din. $\mathrm{He}$ it was, who, like some Laplace born out of due season, beheld the atoms drifting through the mighty void, and discerned with his eyes the beginning of things. And vaguely as he saw these truths, yet he felt among the blind and ignorant multitude like one who sitting safe upon some jutting peak beholds the tempest-driven mariners out at sea tossed by the waves and vainly stretching their hands to their painted gods. As Lucretius felt the beauty and sublimity of the Graco-Roman myths not less but more than other men, so may we well suspect that science will give us in the future not a lower but a higher appreciation of the Sublime, thruughout that immeasurable universe which she is daily opening more and more clearly to our dazzled and astonished graze.

Yet from beginning to end we see that the sense of Sublimity is every where allied with the regulative principle of subordination. The laws of nature rule us now as firmly and inexorably as the savage chieftain rules his naked subjects. And by 
obeying and conforming to those laws we can secure ourselves life and happiness; while by opposing and transgressing their teaching we have our punishment in death and misery. The true place of the Sublime in the scheme of our faculties is next to the regulative and directive ethical feelings: though it forms a connecting link between these and the esthetic sense in its proper acceptation.

Grant allen.

\section{IV.-INTUITION AND INFERENCE.}

\section{I.-INTUITION.}

The meaning of the term Intuition and the scope and limits of the mental capabilities represented thereby have long been unsettled in philosophical speculation. Of so much importance has the name become that its adjective characterises a distinct (or supposed distinct) school in philosophy, whose members claim a proper extension of the denomination beyond what is allowed by their antagonists. With almost all Intuitionalists the name Intuition covers much more than their opponents allow that it can include; in what respects they make such an extension we shall presently see. The applications of the term Inference have notbeen subject to so much doubt and uncertainty as have those of Intuition, though, indeed, it should be said that the fundamental facts of inferential knowledge are not yet so completely laid bare as to leave nothing further for the explorer to do. Intuition and Inference usually are contrasted with each other as being two separate and antithetical modes of mental experience. Intuition is generally referred to as primary and fundamental, while Inference is accounted secondary and superstructive. But as far as one has been made dependent upon the other, mankind has been disposed to mensure Inference by Intuition rather than Intuition by Inference. Intuition has been regarded as a source of or method of obtaining transcendental, pure, and trustwortly knowlelge; while Inference has been esteemed to yield only experiential, mixed, and uncertain information. Intuition is thus held to be the more important, partly because the knowledge it gives is considered to be primary and partly because that knowledge is deemed more clear and certain. Another and very potent reason for the empressement with which Intuition has been treated lies in the fact that men have been alive to the convenience of possessing a standard superior to and independent of Inference, to which they 